\title{
VERY LONG-LIVED MOLLUSKS CONFIRM 17TH CENTURY AD TEPHRA-BASED RADIOCARBON RESERVOIR AGES FOR NORTH ICELANDIC SHELF WATERS
}

\author{
Alan D Wanamaker $\mathrm{Jr}^{1,2} \bullet$ Jan Heinemeier ${ }^{3} \cdot$ James D Scourse $^{1} \bullet$ Christopher A Richardson $^{1} \bullet$ \\ Paul G Butler ${ }^{1} \bullet$ Jón Eiríksson ${ }^{4}$ Karen Luise Knudsen ${ }^{5}$
}

\begin{abstract}
Marine sediment records from the north Icelandic shelf, which rely on tephrochronological age models, reveal an average $\Delta \mathrm{R}$ (regional deviation from the modeled global surface ocean reservoir age) of approximately $150 \mathrm{yr}$ for the last millennium. These tephra-based age models have not hitherto been independently verified. Here, we provide data that corroborate $\Delta \mathrm{R}$ values derived from these sediment archives. We sampled the youngest portion (ontogenetic age) of a bivalve shell, Arctica islandica (L.), for radiocarbon analysis, which was collected alive in 2006 from the north Icelandic shelf in $\sim 80 \mathrm{~m}$ water depth. Annual band counting from the sectioned shell revealed that this clam lived for more than $405 \mathrm{yr}$, making it the longest-lived mollusk and possibly the oldest non-colonial animal yet documented. The ${ }^{14} \mathrm{C}$ age derived from the umbo region of the shell is $951 \pm 27 \mathrm{yr} \mathrm{BP}$. Assuming that the bivalve settled onto the seabed at AD 1600, the corresponding local value of $\Delta \mathrm{R}$ is found to be $237 \pm 35 \mathrm{yr}$ by comparison of the ${ }^{14} \mathrm{C}$ age with the Marine 04 calibration curve (Hughen et al. 2004) at this time. Furthermore, we cross-matched a 287-yr-old, dead-collected, A. islandica shell from AD 1601 to 1656 from the same site with the live-caught individual. ${ }^{14} \mathrm{C}$ analysis from the ventral margin of this shell revealed a $\Delta \mathrm{R}$ of $186 \pm 50 \mathrm{yr}$ at $\mathrm{AD} 1650$. These values compare favorably with each other and with the tephra-based $\Delta \mathrm{R}$ values during this period, illustrating that ${ }^{14} \mathrm{C}$ from $A$. islandica can effectively record ${ }^{14} \mathrm{C}$ reservoir changes in the shelf seas.
\end{abstract}

\section{INTRODUCTION}

Marine sediment archives (Andrews and Giraudeau 2003; Eiríksson et al. 2004, 2006; Giraudeau et al. 2004; Knudsen et al. 2004a,b; Jiang et al. 2005; Sicre et al. 2008) collected from the north Icelandic shelf reveal important changes in North Atlantic ocean circulation and climate during recent millennia. Multiproxy-based evidence derived from these sediment cores shows that the position of the Polar Front has been dynamic (Eiríksson et al. 2004). The oceanic Polar Front is now situated in the Denmark Strait between Greenland and Iceland where the relatively warm and saline waters from the North Atlantic flow clockwise around Iceland, as the Irminger Current, and mix with the relatively cold and lower salinity waters of the East Icelandic Current (Figure 1) (see Stefánsson 1962; Swift 1986; Malmberg and Jónsson 1997; Hansen and Østerhus 2000). Along the north Icelandic shelf, the East Icelandic Current is a mixture of Arctic water derived from the inflow of Atlantic water from the Iceland Sea and Polar water from the East Greenland Current (Stefánsson 1962; Swift and Aagaard 1981; Jónsson 1992). The position of the Polar Front is closely linked to North Atlantic Deep Water convection sites and the North Atlantic meridional overturning circulation (e.g. Austin et al. 1995; Astthorsson et al. 2007; Jónsson 2007), and these strong oceanic and atmospheric gradients make this region particularly sensitive to climate change (Eiríksson et al. 2004; Astthorsson et al. 2007 and references therein). Because the Irminger and East Greenland currents have distinctly different physical properties (temperature and salinity) and radiocarbon reservoir ages (Tauber and Funder 1975; Larsen et al. 2002; Eiríksson et al. 2004), biogenic archives that calcify in these waters reflect the dominant water mass present during biomineralization. As these organisms become part of the sediment record, they preserve paleoenvironmental conditions. However, sediment-based paleoclimate reconstructions depend on reliable age/depth models to accurately assess atmospheric and oceanic temporal responses to climate perturbations, and often they rely on "floating" ${ }^{14} \mathrm{C}$ ages with uncertain reservoir corrections from mollusks or foraminifera

\footnotetext{
${ }^{1}$ School of Ocean Sciences, College of Natural Sciences, Bangor University, Wales LL59 5AB, United Kingdom.

${ }^{2}$ Corresponding author. Email: a.wanamaker@bangor.ac.uk.

${ }^{3}$ AMS ${ }^{14} \mathrm{C}$ Dating Centre, Department of Physics and Astronomy, University of Aarhus, DK-8000 Aarhus C, Denmark.

${ }^{4}$ Earth Science Institute, Askja, University of Iceland, IS-101 Reykjavík, Iceland.

${ }^{5}$ Department of Earth Sciences, University of Aarhus, DK-8000 Aarhus C, Denmark.
} 
within the sediment record to constrain the age/depth relationship. Because of the dynamic nature of ${ }^{14} \mathrm{C}$ reservoir ages across the Polar Front, using age models based on floating ${ }^{14} \mathrm{C}$ ages from biogenic carbonates may be inadequate and may mask important paleoenvironmental data. Eiríksson et al. (2004) found significant deviations in $\Delta \mathrm{R}$ (defined as the regional deviation from the modeled global surface ocean reservoir age of about $405{ }^{14} \mathrm{C}$ yr; see Hughen et al. 2004) between tephra-based and floating ${ }^{14} \mathrm{C}$ age model values for north Icelandic shelf waters during the Holocene. Tephrochronological age models seek to improve the reconstruction of temporal changes in the ${ }^{14} \mathrm{C}$ reservoir age near the Polar Front by providing exactly dated anchors in the sediment records. This approach also enables the use of deviations in $\Delta \mathrm{R}$ as a paleoceanographic tool for tracking past changes in the position of the Polar Front (Eiríksson et al. 2004).

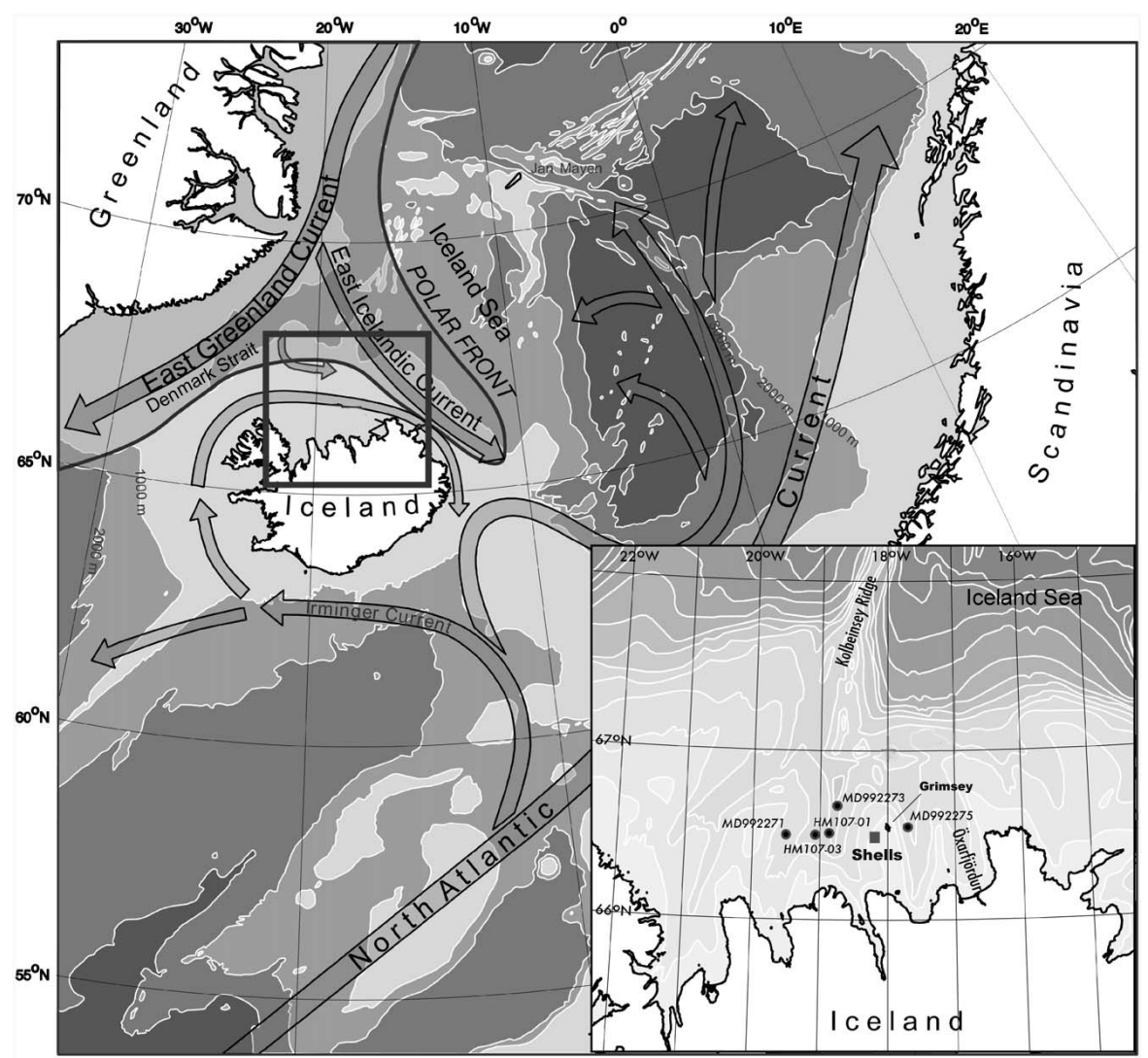

Figure 1 Site location map showing the major surface currents and the position of the modern Polar Front (modified from Eiríksson et al. 2004). The study area is noted by the black box, with the inset map showing the sediment core records (MD99-2271, HM107-03, HM107-01, MD99-2273, MD99-2275) and the shell collection region; contour line on the insert map $=100 \mathrm{~m}$.

The north Icelandic shelf is an ideal region to use tephrochronology to constrain sediment age/depth relationships because of its high sedimentation rates $(>0.20 \mathrm{~cm} / \mathrm{yr})$ and its close proximity to the numerous source volcanoes for Holocene tephras (Larsen et al. 2002). Five marine sediment cores from the north Icelandic shelf reveal a variable $\Delta \mathrm{R}$ of $156 \pm 116 \mathrm{yr}$ for the last millennium (Figure 2). Although tephra-based age models may offer significant advantages over floating ${ }^{14} \mathrm{C}$ 
age models, these tephra-based age models from the north Icelandic shelf have not been independently verified (Eiríksson et al. 2004).

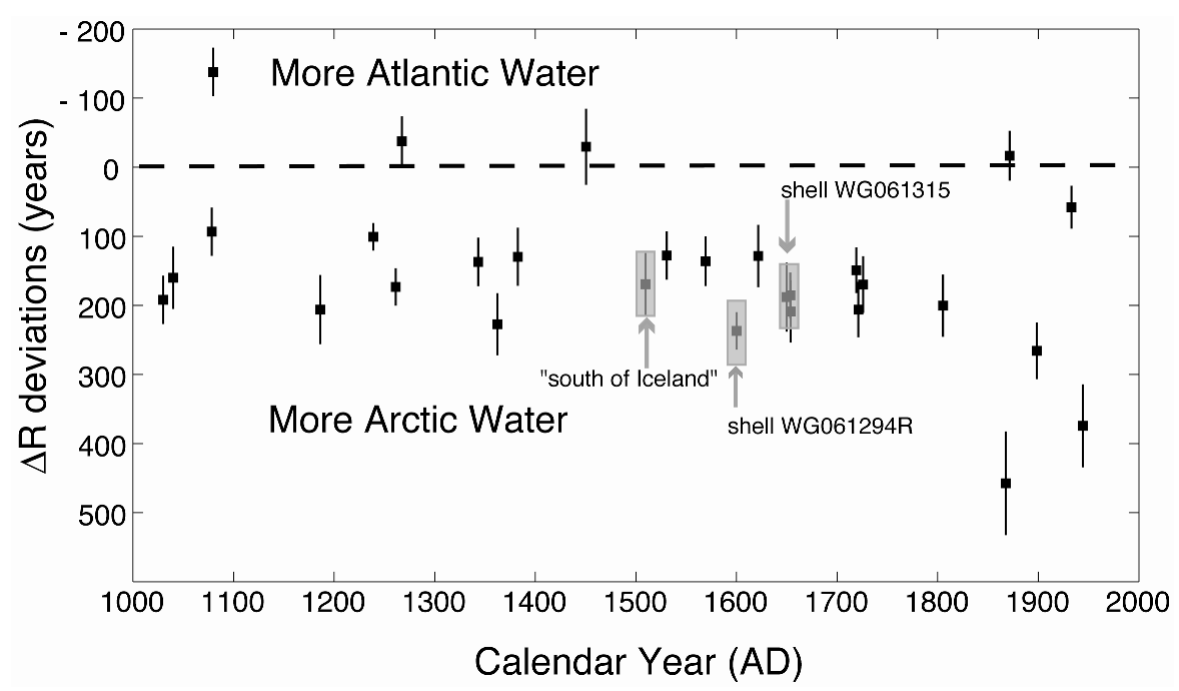

Figure $2 \Delta \mathrm{R}$ deviations from the north Icelandic shelf for the last $1000 \mathrm{yr}$ (the data are from Eiríksson et al. 2004: Figure 10). The $\Delta \mathrm{R}$ deviations from Eiríksson et al. (2004) are based on 5 sediment core records (MD99-2271, HM107-03, HM107-01, MD99-2273, MD99-2275) using a tephra-based age model. Shell-based $\Delta \mathrm{R}$ deviations from this study are shown for AD 1600 and AD 1650 (see arrows and shading). The newly calculated $\Delta \mathrm{R}$ value at AD 1497 from the 374-yr-old Arctica islandica shell reported by Schöne et al. (2005a) is shown as "south of Iceland" (see Discussion for details). More negative $\Delta \mathrm{R}$ values indicate a dominant Atlantic water mass, while positive $\Delta \mathrm{R}$ values indicate a dominant Arctic water mass (Eiríksson et al. 2004).

Marine biogenic carbonates that are long-lived (corals, sclerosponges, and mollusks) and of known collection dates have the potential to monitor changes in the uptake and mixing of ${ }^{14} \mathrm{C}$ in the oceans through time and contribute to a better understanding of climate change. The use of ${ }^{14} \mathrm{C}$ in seawater in the form of dissolved inorganic carbon as a water-mass tracer began decades ago (Broecker and Olson 1961), and in the late 1970 s, coral ${ }^{14} \mathrm{C}$ was used to monitor changes in ocean circulation and climate change (e.g. Druffel and Linick 1978; Druffel 1980, 1982, 1989; Guilderson et al. 1998, 2004; Kilbourne et al. 2007; Druffel et al. 2007, 2008). Recently, Kilbourne et al. (2007) produced a subdecadal ${ }^{14} \mathrm{C}$ time series from a Puerto Rico coral (Montastraea faviolata) from AD 1750 to 2000 that showed significant decadal variability likely related to the advection of different water masses into the Caribbean Sea, and possible changes in the Atlantic meridional overturning circulation. Druffel et al. (2007) provided an ultra-high resolution (annual) ${ }^{14} \mathrm{C}$ time series from the Galápagos Islands in the tropical east Pacific based on a coral colony with annual banding (Pavona clavus), which demonstrated the natural variability of the oceanic ${ }^{14} \mathrm{C}$ since AD 1600 . However, in the extratropics there have been few, if any, published studies that have yielded a well-constrained (temporally), high-resolution time series of ${ }^{14} \mathrm{C}$ variability prior to the atmospheric bomb pulse of the 1950s. Weidman and Jones (1993) first demonstrated the utility of the ${ }^{14} \mathrm{C}$ signature extracted from the annually-banded shell material of the long-lived bivalve Arctica islandica (Linnaeus 1767) for tracking the oceanic uptake of bomb ${ }^{14} \mathrm{C}$ in the northwestern Atlantic (Georges Bank). Moreover, Weidman and Jones (1993) showed that shells sampled for ${ }^{14} \mathrm{C}$ from Georges Bank had an attenuated response to the atmospheric bomb ${ }^{14} \mathrm{C}$ produced during atomic testing in the 1950 s compared 
to tropical corals; this result illustrated important hydrographic differences controlling the rates at which atmospheric carbon is mixed into the oceans, and it also suggested a deepwater source for the waters of Georges Bank. Furthermore, annual growth records and geochemical information $\left(\delta^{18} \mathrm{O}\right)$ derived from the shells of $A$. islandica have been used to study past ocean conditions in the North Atlantic (Weidman et al. 1994; Witbaard 1996; Witbaard et al. 1997, 2003; Marsh et al. 1999; Marchitto et al. 2000; Schöne et al. 2003, 2004, 2005a; Scourse et al. 2006; Helama et al. 2007; Wanamaker et al. 2008). These shell-based records, like tree rings, offer a significant advantage of being absolutely dated (Thompson et al. 1980; Jones 1980), and therefore enable the generation of ultrahigh-resolution paleoenvironmental records based on an absolute timescale (Marchitto et al. 2000). The chronostratigraphy developed from these biogenic carbonates is equivalent to varved sea sediments, which are generally rare. However, A. islandica is common in the shelf seas of the temperate to subpolar North Atlantic and has enormous potential as a high-resolution marine archive. Marchitto et al. (2000) demonstrated that live-caught $A$. islandica shells could be reliably cross-matched with fossil (dead-collected) shells; thus, regional reconstructions in $\Delta \mathrm{R}$ on centennial-to-millennial scales are possible if there is sufficient fossil shell material available. Because fossil shells can be linked to recent shells through cross-matching techniques, $\Delta \mathrm{R}$ reconstructions can extend further back in time than those based on individual live shells with a temporal resolution higher than tephrabased methods. This method will be extremely valuable in regions where tephra is sparse or absent.

In this paper, we provide independent ${ }^{14} \mathrm{C}$ evidence from an Arctica islandica shell more than $400 \mathrm{yr}$ old (live-caught in 2006), and a 286-yr-old subfossil shell, which supports relatively high $\Delta \mathrm{R}$ values for the north Icelandic shelf waters during the 17 th century. These results are consistent with ${ }^{14} \mathrm{C}$ reservoir ages based on tephra-based age models from nearby sediment archives. These 2 shells were successfully linked together by cross-matching, a technique commonly used in dendrochronology, thus creating a continuous shell chronology from AD 1373 to 2005. Here, we further demonstrate that information derived from the shells of the bivalve A. islandica can be used to study extra-tropical ocean circulation and environmental change. Its great longevity, its fidelity as a proxy record, and its abundance and wide geographical distribution make A. islandica a key proxy archive for the North Atlantic region.

\section{METHODS}

\section{Shell Collection}

The 2 shells studied in this paper were part of a collection of live, dead articulated, and dead single valves of Arctica islandica collected by trawling the seabed surface with a bespoke dredge on the north Icelandic shelf (see Figure 1) in June 2006 from the research vessel Bjarni Samundsson (Cruise No. B05-2006). Live specimens were frozen onboard and processed following thawing soon after return to the laboratory, whereupon the soft tissues were removed and the shell valves scrubbed clean and dried prior to processing. The 2 shells reported in this study (WG061294R and WG061315) were collected near the island of Grimsey $\left(66^{\circ} 31.59^{\prime} \mathrm{N}, 18^{\circ} 11.74^{\prime} \mathrm{W}\right.$; see Figure 1) in a water depth of 81-83 m (trawl B05AD03) and were selected because they were relatively large and heavily calcified. Shell WG061294R was collected alive, while the right shell valve WG061315 was from a dead, non-articulated clam.

\section{Shell Preparation and Sclerochronology}

The annually resolved growth lines were identified in acetate peel replicas (Ropes 1984) of polished and etched shell sections of the hinge tooth at the umbo of the shell (Figure 3). The right and left shell valves of WG061294R and the right shell valve of WG061315 were embedded in resin (Met- 
Prep Ltd; Kleer Set type FF) and the shells sectioned radially from the umbo to the shell margin. The embedded left valve was sectioned through the center of the hinge tooth, whereas the right hinge shell valve was sectioned radially to the side of the tooth using a diamond saw. The cut surfaces were ground on progressively finer grades of silicon carbide paper (MetPrep Ltd; P120, P400, P1200) and
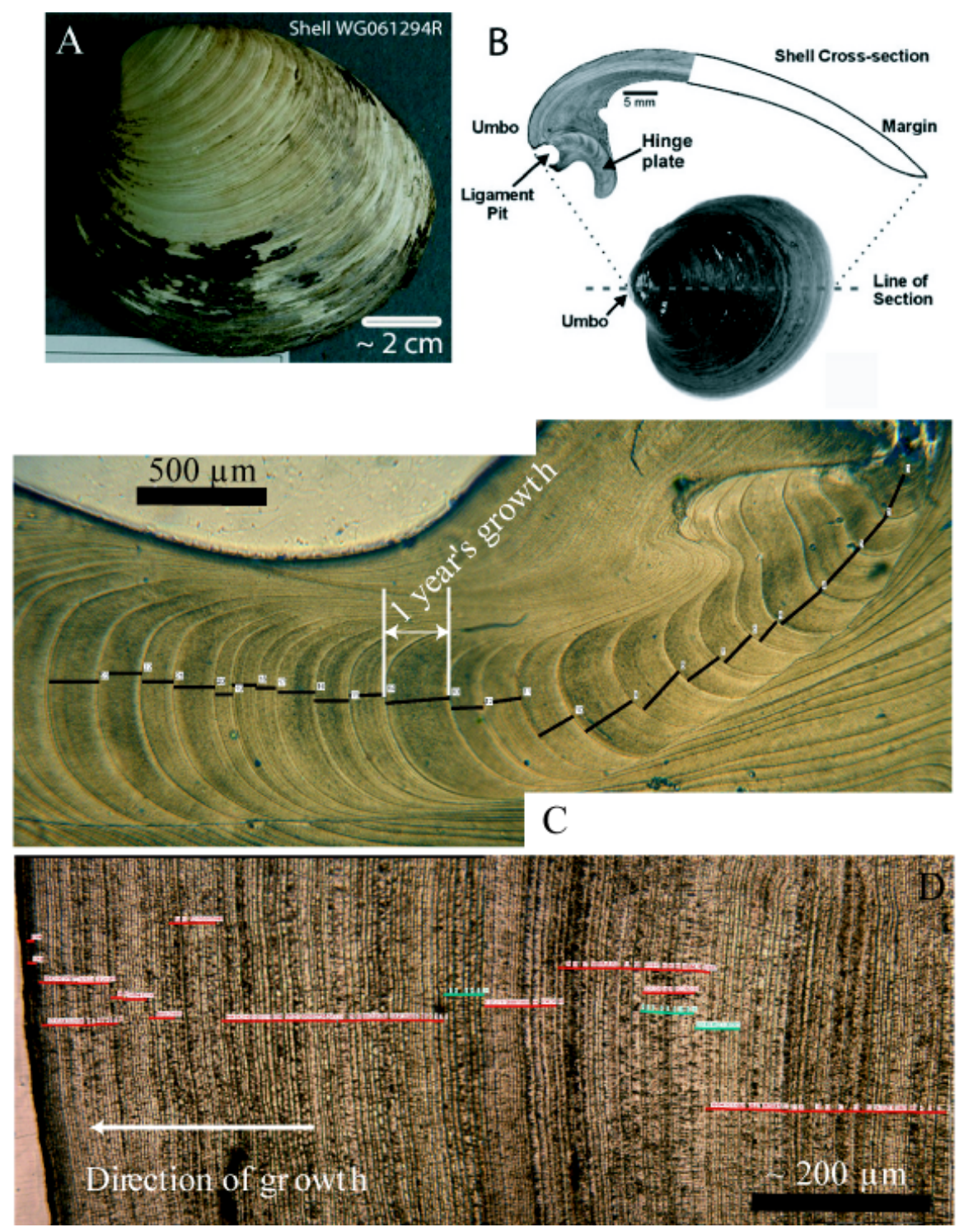

Figure 3 (A) Left valve of Arctica islandica shell WG061294R collected from the north Icelandic shelf. (B) Idealized line of section, and an A. islandica shell cross-section noting the major features (modified from Scourse et al. 2006). (C) Digitized photomicrograph (magnification $=\times 2.5$ ) of an acetate peel from a young portion of an A. islandica sample from the hinge plate collected from the Grimsey site. One yr of shell growth is measured from 1 growth check to the next, which is shown in white. The first 23 annual growth increments are shown in black. (D) Digitized photomicrograph (magnification $=\times 10$ ) of an acetate peel from shell WG061294R with approximately the last $175 \mathrm{yr}$ of growth in the hinge plate. 
polished with dilute diamond paste (Presi; $3 \mu \mathrm{m}$ ) on rotary magnetic pads (Presi; $200 \mathrm{~mm}, 3106$ and 0307) and etched in a modified Mutvei solution (without alcian blue) at room temperature for 45 min (see Schöne et al. 2005b). Acetate peel replicas (Agar Scientific; $35 \mu \mathrm{m}$ ) of the polished and etched surfaces were prepared and examined in transmitted light under magnifications of $\times 2.5, \times 4$, and $\times 10$ using a Leica Laborlux $\mathrm{S}$ microscope. Following the production of acetate peel replicas, annual growth increment widths can be measured and recorded either from the outer shell surface (Schöne et al. 2005a) or along the hinge plate in the umbo (Scourse et al. 2006). The hinge plate was used because the growth increments here are most obvious (Figure 3C). Because of its great longevity, shell WG061294R was measured by 3 operators at the same time; only growth checks that were mutually agreed upon by all operators were counted. Images of the incremental record in the sectioned hinge plates were captured using a digital camera (Soft Imaging Systems; Colorview) and the increment widths measured using the software analySIS ${ }^{\circledR} 3.2$ (Figure 3C). This system facilitates increment measurement using an automated cursor that feeds directly into a data spreadsheet and enables both the growth increment series and their axis of measurement to be digitized. Because of the nature of the $A$. islandica growth curve, where yearly growth can vary by 2 orders of magnitude over the lifespan of the animal, the raw increment-width data are treated using a high-pass filter that removes the low-frequency ontogenetic growth trend to produce a standard shell growth-increment plot for each shell (Scourse et al. 2006). This involves generating the natural logarithm of the data to remove the different orders of magnitude and the residuals are then taken from a 15-yr spline through the data (Figure 4A). This detrending method is optimal for cross-matching shell growth records and chronology construction.

\section{Radiocarbon Analysis}

The periostracum was removed by scraping the outer shell surface using a razor blade near the targeted region for ${ }^{14} \mathrm{C}$ sampling. Approximately a 30-mg solid sample of shell carbonate was cut with a razor blade and removed from the outer shell surface (Figure 3B) from the umbo region of the shell WG061294R and from the ventral margin (adjacent to the axis of maximum growth) of shell WG061315. The shell samples were treated following a standard mollusk rinsing procedure at the University of Aarhus (Denmark): to eliminate any possible surface contamination, the outer $25 \%$ of the shell was removed by etching in $1 \mathrm{M} \mathrm{HCl}$. Any organic carbon incorporated in the shell carbonate was removed by treatment with a $\mathrm{KMnO}_{4}$ solution for $16-20 \mathrm{hr}$ at $80^{\circ} \mathrm{C}$. The $\mathrm{CO}_{2}$ was liberated with $\sim 100 \%$ phosphoric acid in an evacuated vial at $25^{\circ} \mathrm{C}$. Part of the $\mathrm{CO}_{2}$ was used for $\delta^{13} \mathrm{C}$ measurements; the rest was converted to graphite for accelerator mass spectrometry (AMS) ${ }^{14} \mathrm{C}$ measurements by reduction with $\mathrm{H}_{2}$, with cobalt as a catalyst (Vogel et al. 1984).

All AMS ${ }^{14} \mathrm{C}$ measurements were carried out using the $\mathrm{EN}$ tandem accelerator at the University of Aarhus. The dating results are reported according to international convention (Stuiver and Polach 1977) as conventional ${ }^{14} \mathrm{C}$ dates in ${ }^{14} \mathrm{C}$ yr BP (before $\mathrm{AD}$ 1950) based on the measured ${ }^{14} \mathrm{C} /{ }^{13} \mathrm{C}$ ratio corrected for the natural isotopic fractionation by normalizing the result to the standard $\delta^{13} \mathrm{C}$ value of $-25 \%$ o VPDB (Andersen et al. 1989). The results are shown in Table 1.

\section{RESULTS}

\section{Ontogenetic Age and Radiocarbon Analysis}

Four hundred and five annual bands were counted in the sectioned hinge area for shell WG061294R. Part of this record ( last $175 \mathrm{yr}$ ) is shown in Figure 3D. This is the oldest mollusk known to science, and perhaps the oldest documented non-colonial animal. As this clam was live-caught in 2006, we assigned a calendar year to each annual increment beginning in 2005, and based on this method, we 

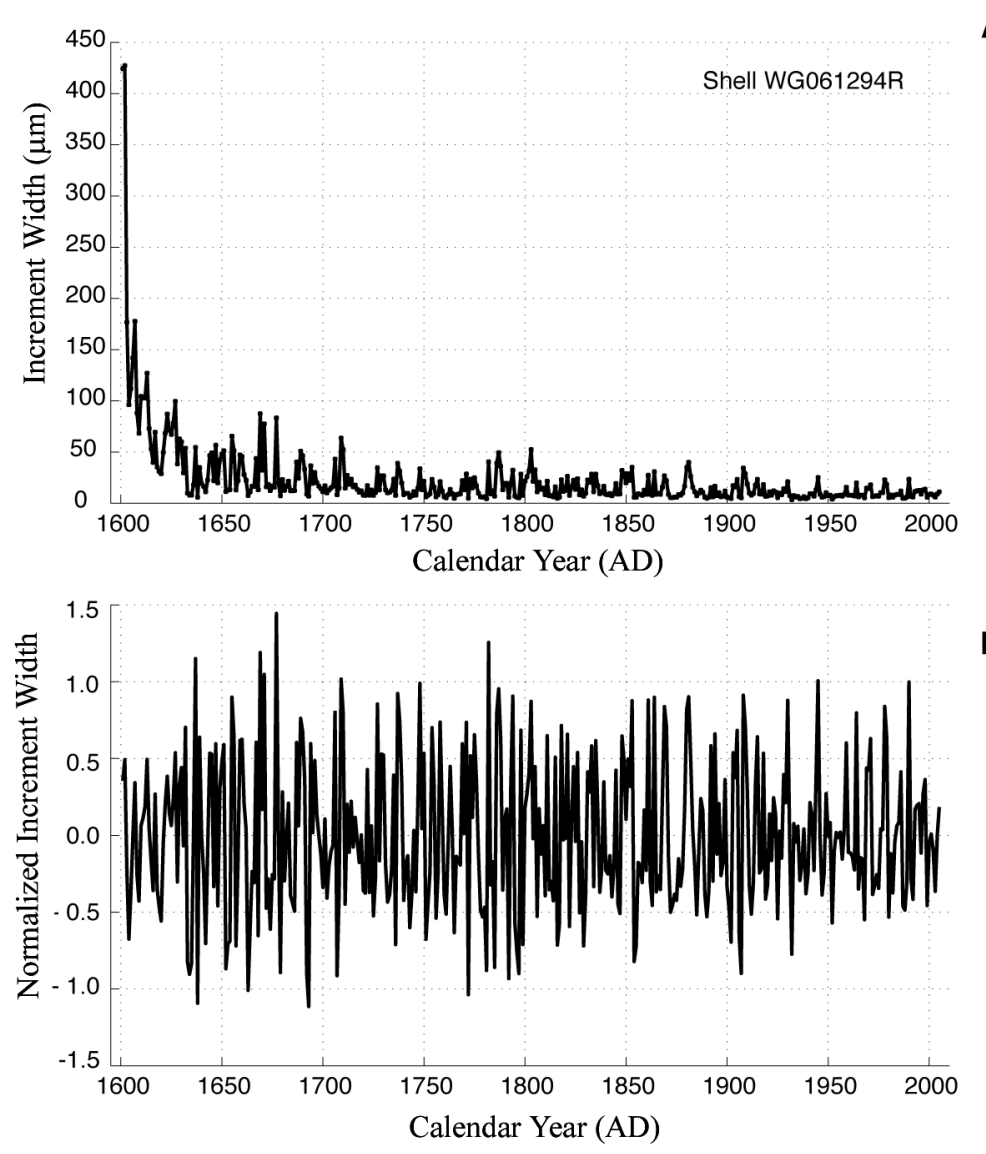

Figure 4 (A) Raw annual increment width measurements from shell WG061294R. (B) Standardized increment width time series for the same shell. The data were first treated with a natural logarithm to normalize the variance through time, then the ontogenetic growth trend was removed with a 15 -yr cubic spline function.

Table 1 Summary of ${ }^{14} \mathrm{C}$ analyses for A. islandica shells WG061294R and WG061315 from the Grimsey site along the north Icelandic shelf. Sclerochronological ages were determined by counting the annual increments in the sectioned shells. Shell WG061294R was live-caught in AD 2006, while shell WG061315 was dead-collected and cross-dated with shell WG061294R (see text for details).

\begin{tabular}{llllll}
\hline Laboratory ID & Sample ID & $\begin{array}{l}{ }^{14} \mathrm{C} \text { age } \\
(\mathrm{yr} \mathrm{BP}) \pm 1 \sigma\end{array}$ & $\begin{array}{l}\delta^{13} \mathrm{C} \\
(\% \circ)\end{array}$ & $\begin{array}{l}\text { Sclerochronological } \\
\text { age of sample }(\mathrm{AD})\end{array}$ & $\begin{array}{l}\text { Calculated } \\
\Delta \mathrm{R} \pm 1 \sigma\end{array}$ \\
\hline AAR-11784 & 61294 & $951 \pm 27$ & 2.58 & 1600 & $237 \pm 35$ \\
AAR-11784 & 61315 & $863 \pm 45$ & 1.93 & 1650 & $186 \pm 50$ \\
\hline
\end{tabular}

suggest that this animal settled onto the seafloor north of Iceland in AD 1600. Subfossil shell WG061315 contained 284 annual bands. The actual age of each clam is at least $2 \mathrm{yr}$ older than the number of annual bands counted (407 and 286, respectively), because the first and last years of life do not form complete annual increments. The umbo portion (within the first ontogenetic year) of WG061994R had a ${ }^{14} \mathrm{C}$ age of $951 \pm 27 \mathrm{BP}$. The ventral margin of shell WG061315 had a ${ }^{14} \mathrm{C}$ age 
of $863 \pm 45 \mathrm{BP}$ (Table 1). This sample was integrated over approximately $10 \mathrm{yr}$ (growth increments), corresponding to an average date of growth around AD 1650. Although we sampled the relatively fast-growing juvenile portion in shell WG061994R and the relatively slow-growing adult portion of shell WG061315 for ${ }^{14} \mathrm{C}$ analyses, we conclude that this methodology did not bias our results. In fact, Schöne (2005a: Figure 6 on page 138) demonstrated that carbon and oxygen isotopes from the aragonitic material of an A. islandica shell from Iceland were not impacted by vital effects during the first $39 \mathrm{yr}$ of growth. Additionally, earlier work by Weidman and Jones (1993) showed no evidence to support an ontogenetic-related effect for the incorporation of ${ }^{14} \mathrm{C}$ into the shell material of A. islandica.

\section{$\Delta R$ and Cross-Matching}

As the oldest shell (WG061294R) was live-caught in 2006, the calculation of $\Delta \mathrm{R}$ was determined by comparing the measured ${ }^{14} \mathrm{C}$ age with the ${ }^{14} \mathrm{C}$ value of the Marine 04 calibration curve (Hughen et al. $2004)$ at $\mathrm{AD} 1600(714 \pm 23 \mathrm{BP})$. This analysis produced a $\Delta \mathrm{R}$ of $237 \pm 35$ at AD 1600 (Figure 2). The standardized incremental growth series between shells WG061294R and WG061315 were cross-matched with the visualization software program SHELLCORR (see Scourse et al. 2006 for details) (Figures 5,6), initially using a $\Delta \mathrm{R}$ of 250. We chose this $\Delta \mathrm{R}$ value based on the result from the live-caught shell WG061294R and the relatively high $\Delta \mathrm{R}$ values revealed from nearby sediment archives (Eiríksson et al. 2004). SHELLCORR allows 2 time series to be compared with various time lags (up to $\pm 250 \mathrm{yr}$ ) (Figure 6) to account for mismatched calendar ages, or floating ${ }^{14} \mathrm{C}$ estimates. Once a statistically significant cross-match is achieved, the calendar age of the deadcollected clam can be refined. We successfully cross-matched the subfossil shell with the livecaught shell (Figure 6). The correlation between the 2 growth indices during the overlap interval (AD 1601 to 1656) was highly significant $(r=0.66 ; p<0.0001)$. To further assess the strength of the agreement between the 2 shell growth records, we used the $t$ statistic by Baillie and Pilcher (1973), which is shown below (Equation 1):

$$
t=\frac{r \sqrt{n-2}}{\sqrt{1-R^{2}}}
$$

Based on the correlation coefficient $(r)$, the coefficient of determination $\left(R^{2}\right)$, and the number of overlapping years $(n)$, the $t$ statistic between the 2 shells is 8.51 , which is substantially higher than the critical value of 3.5. Pilcher et al. (1995) further suggested that a $t$ value of 4.0 may be significant and values greater than 6.0 are very likely to be significant. These results suggest that it is extremely unlikely that the cross-match between these 2 shells is due to chance alone, but the addition of another shell in the chronology during this interval will improve the strength of this argument. Based on the cross-matched relationship, we have assigned a sclerochronological lifespan to the subfossil shell WG061315 from AD 1373 to 1656; a settlement date of AD 1373 and death at AD 1656. ${ }^{14} \mathrm{C}$ analysis of $\sim 10$ increments taken from the ventral margin of this shell revealed a $\Delta \mathrm{R}$ of $186 \pm 50 \mathrm{yr}$ at AD 1650 (Figure 2), close to the estimated date of death determined from the sclerochronological record. These values compare well with each other and with the tephra-based $\Delta \mathrm{R}$ values for the north Icelandic shelf during this period (see Table 1 and Figure 2).

\section{DISCUSSION}

In this study, we have demonstrated that a long-lived $(400+\mathrm{yr})$, live-caught Arctica islandica shell can be successfully cross-matched with a subfossil specimen, thus creating and extending a dated shell growth increment chronology (>600 yr), i.e. AD 1373-2005 (Figure 5 top), for Icelandic 

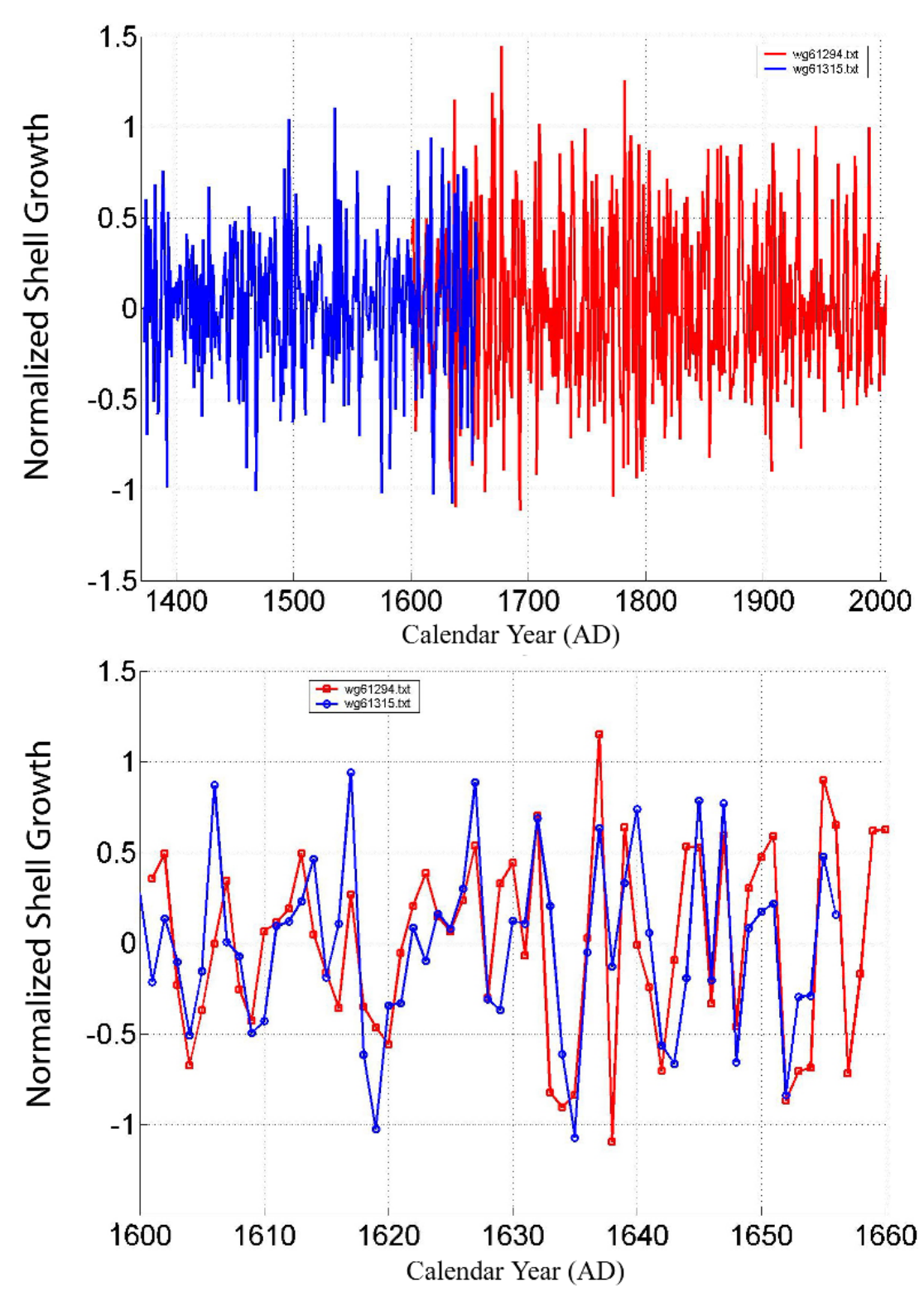

Figure 5 (Top) Normalized shell growth records from WG061294R (red) and WG061315 (blue) based on ${ }^{14} \mathrm{C}$ analysis and cross-matching techniques. (Bottom) Cross-match between the 2 shells from $\mathrm{AD} 1601$ to 1656 . The correlation between the 2 shells during the overlap interval was highly significant $(r=0.66 ; p<0.0001 ; t$ statistic $=8.51$ after Baillie and Pilcher 1973).

waters. We have also shown that the widely spaced growth increments deposited during the first $50 \mathrm{yr}$ of life by the old live-collected clam (WG061294R) could be successfully and robustly crossmatched with the narrow growth increments deposited in the older shell portions of the subfossil clam shell (WG061315) once the incremental growth series are standardized (Figure 5 bottom). 


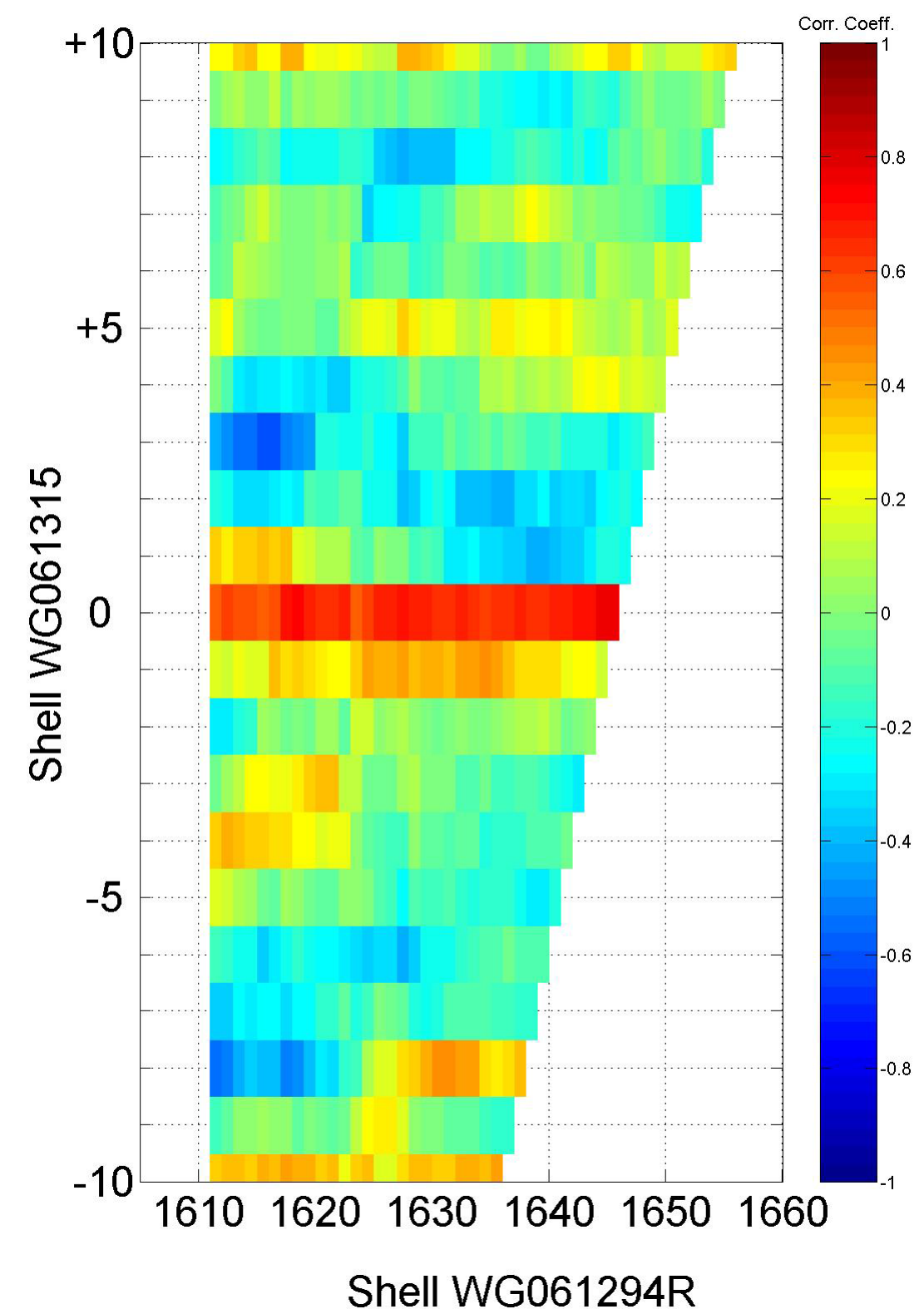

Figure 6 SHELLCORR output with the correct temporal alignment of shell WG061315, and noting the strength of the correlation during the overlap period (calendar yr $\mathrm{AD}$ ) using a 21 -yr sliding window.

The results presented here further demonstrate that the ${ }^{14} \mathrm{C}$ content of annually-banded Arctica islandica growth increments has the potential to document past ocean conditions, including the reservoir ages of the shelf seas in the North Atlantic (Weidman and Jones 1993). Furthermore, we have independently verified the tephra-based $\Delta \mathrm{R}$ values for the north Icelandic shelf during the 17 th century. The shell and sediment-derived $\Delta \mathrm{R}$ data overlap once the analytical errors are considered when calculating $\Delta \mathrm{R}$ values (Figure 2). It is often difficult to determine phase relationships (lead or lag) 
between climate perturbations and the response of the system(s) of interest. Sediment-based paleoclimate reconstructions that rely on tephra-based age/depth models (Eiríksson et al. 2006; Sicre et al. 2008) offer the unique opportunity to accurately capture the temporal response of the ocean with respect to climate perturbations when tephra is abundant through time. However, when tephra is less abundant or absent, high-resolution (decadal-scale) shell-based $\Delta \mathrm{R}$ reconstructions can fill in gaps between the tephra layers or provide an alternative method for monitoring ${ }^{14} \mathrm{C}$ reservoir changes. This technique will be especially important south of Iceland where tephra is scarce. The relatively high $\Delta \mathrm{R}$ values of $237 \pm 35$ and $186 \pm 50$, at AD 1600 and 1650, respectively, derived from $A$. islandica and the data of Eiríksson et al. (2004) (Figure 2) indicate a pervasive presence of Arctic water over the north Icelandic shelf during the beginning and middle of the 17th century. This interpretation is consistent with paleoceanographic evidence that suggests the shelf region north of Iceland was extremely cold during this interval of the Little Ice Age (Knudsen et al. 2004a; Jiang et al. 2005; Eiríksson et al. 2006; Sicre et al. 2008). In addition, Schöne et al. (2005a) sampled the umbo portion of a museum-archived A. islandica shell to confirm its great sclerochronological age of $\sim 374 \mathrm{yr}$ old. This shell was originally collected from the south Icelandic shelf, but because its exact location was not known, the incremental series cannot be used with any great certainty to reconstruct the $\Delta \mathrm{R}$ of the water mass and oceanic circulation around Iceland. Schöne et al. (2005a) have suggested that the clam may have been collected from either the eastern or western shelf south of Iceland. However, as the clam was collected alive in July 1868 , a ${ }^{14} \mathrm{C}$ reservoir age can be determined. We calculated the ${ }^{14} \mathrm{C}$ reservoir age of this shell to be $150 \pm 45$ based on the published ${ }^{14} \mathrm{C}$ value in Schöne et al. (2005a; uncalibrated ${ }^{14} \mathrm{C}$ age $=950 \pm 40 \mathrm{BP}$ from $\mathrm{AD} 1497$ ) a value that is close to $\Delta \mathrm{R}$ values observed on the north Icelandic shelf at about AD 1500 (see Figure 2). From these observations, we suggest that this shell was probably collected from the eastern portion of the shelf (see Schöne et al. 2005a; Figure 1). As the East Icelandic Current flows clockwise around Iceland from the north to the south (Figure 1), it can bring relatively depleted waters with respect to ${ }^{14} \mathrm{C}$ $(\Delta R>150)$, due to the contribution of Arctic water masses (Tauber and Funder 1975). In contrast, the southwestern Icelandic waters are primarily influenced by the Irminger Current, which is relatively enriched with respect to ${ }^{14} \mathrm{C}$ due to prolonged air-sea exchange ( $\Delta \mathrm{R}$ near 0$)$. Although this new $\Delta \mathrm{R}$ value (150 \pm 45 at $\mathrm{AD} 1497)$ south of Iceland should be used with caution because the exact location of the shell is not known, it does suggest a strong influence of Arctic waters north of Iceland during this interval, which is consistent with the data presented in Figure 2. In contrast, according to the CHRONO Marine Reservoir Database (http://intcal.qub.ac.uk/marine), there are 11 previous reservoir determinations made on pre-bomb live-collected shells from coastal sites around Iceland. The weighted mean $\Delta \mathrm{R}$ value is $52 \mathrm{yr}$, and the values range from 56 to +225 , exhibiting a standard deviation of $71 \mathrm{yr}$. In general, this would indicate a shift from an Arctic water mass to an Atlantic water source in the recent centuries, perhaps representing the end of the Little Ice Age. The data presented in Figure 2 illustrate a highly dynamic water mass north of Iceland since AD 1800. A decadal-scale reconstruction of $\Delta \mathrm{R}$ during this interval would substantially improve our understanding of the processes impacting the climate and oceanography north of Iceland, especially during a time of increased anthropogenic influence on Earth's climate. We are currently constructing such a record, and we are confident that the ${ }^{14} \mathrm{C}$ from A. islandica shells will elicit important oceanographic information, including hydrographic changes and possibly the relative position of the Polar Front north of Iceland.

\section{CONCLUSION}

Here, we provide independent evidence that supports tephra-based age models for the north Icelandic shelf during the 17 th century AD. ${ }^{14} \mathrm{C}$ analyses from the 2 long-lived Arctica islandica shells dis- 
cussed in this paper reveal a $\Delta \mathrm{R}$ of $237 \pm 35$ at $\mathrm{AD} 1600$ and a $\Delta \mathrm{R}$ of $186 \pm 50 \mathrm{yr}$ at $\mathrm{AD} 1650$, respectively. In terms of the oceanographic setting during this interval, it appears that the north Icelandic shelf was dominated by an Arctic water mass. This result is consistent with nearby sediment-based studies that indicate that the shelf region north of Iceland was extremely cold during this interval of the Little Ice Age. Further, we have shown that there is potential to match the growth series from livecaught $A$. islandica shells with dead-collected specimens, which could lead to the construction of very long, absolutely dated, shell chronologies. We have demonstrated that even young shell portions can be cross-matched with older shell portions once the incremental series from the shells are standardized. In addition, with the 2 shells discussed in this paper, we have developed a shell-growth chronology spanning more than 6 centuries (AD 1373-2005). These shells will serve as a template for constructing a master shell chronology for the past millennium, which will be used to assess the evolution of climate and oceanographic change north of Iceland. The great longevity of $A$. islandica, its precise temporal control, its abundance through geologic time, and its broad distribution in the temperate North Atlantic make it a key marine proxy to study past oceanic environments.

\section{ACKNOWLEDGMENTS}

We thank the crew from the research vessel Bjarni Samundsson (Cruise No. B05-2006) and the members who participated on the research cruise. We thank Brian Long (Bangor University) for his technical support, and Ian Harris (University of East Anglia) for the SHELLCORR program. We thank 2 anonymous reviewers for their comments and suggestions, which improved the content and flow of this paper. This research is funded by EU Millennium (European Climate of the Last Millennium; Project no. 017008). JDS acknowledges a Royal Society-Leverhulme Trust Senior Research Fellowship.

\section{REFERENCES}

Andersen GJ, Heinemeier J, Nielsen HL, Rud N, Thomsen MS, Johnsen S, Sveinbjörnsdóttir Á, Hjartarson Á. 1989. AMS ${ }^{14} \mathrm{C}$ dating on the Fossvogur sediments, Iceland. Radiocarbon 31(3):592-600.

Andrews JT, Giraudeau J. 2003. Multi-proxy records showing significant Holocene environmental variability: the inner N. Iceland shelf (Húnaflói). Quaternary Science Reviews 22(2-4):175-93.

Astthorsson OS, Gislason A, Jónsson S. 2007. Climate variability and the Icelandic marine ecosystem. DeepSea Research Part II 54(23-26):2456-77.

Austin WEN, Bard E, Hunt JB, Kroon D, Peacock JD. 1995. The ${ }^{14} \mathrm{C}$ age of the Icelandic Vedde Ash: implications for Younger Dryas marine reservoir age corrections. Radiocarbon 37(1):53-62.

Baillie MGL, Pilcher JR. 1973. A simple cross-dating program for tree-ring research. Tree-Ring Bulletin 33: 7-14.

Broecker WS, Olson EA. 1961. Lamont radiocarbon measurements VIII. Radiocarbon 3(1):176-204.

Druffel EM. 1980. Radiocarbon in annual coral rings of Belize and Florida. Radiocarbon 22(2):363-71.

Druffel EM. 1982. Banded corals: changes in oceanic carbon-14 during the Little Ice Age. Science 218(4567):13-9.

Druffel ERM. 1989. Decade time scale variability of ventilation in the North Atlantic: high-precision measurements of bomb radiocarbon in banded corals. Journal of Geophysical Research-Oceans 94(C3): 3271-85.

Druffel EM, Linick TW. 1978. Radiocarbon in annual coral rings of Florida. Geophysical Research Letters 5(11):913-6.

Druffel ERM, Griffin S, Beaupré SR, Dunbar RB. 2007. Oceanic climate and circulation changes during the past four centuries from radiocarbon in corals. Geophysical Research Letters 34(9): L09601, doi: 10.1029/2006GL028681.

Druffel ERM, Robinson LF, Griffin S, Halley RB, Southon JR, Adkins JF. 2008. Low reservoir ages for the surface ocean from mid-Holocene Florida corals. Paleoceanography 23(2): PA2209, doi:10.1029/ 2007 PA001527.

Eiríksson J, Larsen G, Knudsen KL, Heinemeier J, Símonarson LA. 2004. Marine reservoir age variability and water mass distribution in the Iceland Sea. Quaternary Science Reviews 23(20-22):2247-68.

Eiríksson J, Bartels-Jónsdóttir HB, Cage AG, Gudmundsdóttir ER, Klitgaard-Kristensen D, Marret F, Rodrigues T, Abrantes F, Austin WEN, Jiang H, Knudsen KL, Sejrup H-P. 2006. Variability of the North Atlantic Current during the last 2000 years based on shelf bottom water and sea surface temperatures along an open ocean/shallow marine transect in 
western Europe. The Holocene 16(7):1017-29.

Giraudeau J, Jennings AE, Andrews JT. 2004. Timing and mechanisms of surface and intermediate water circulation changes in the Nordic Seas over the last 10,000 cal years: a view from the North Iceland shelf. Quaternary Science Reviews 23(20-22):2127-39.

Guilderson TP, Schrag DP, Kashgarian M, Southon J. 1998. Radiocarbon variability in the western equatorial Pacific inferred from a high-resolution coral record from Nauru Island. Journal of Geophysical Re search-Oceans 103(C11):24,641-50.

Guilderson TP, Schrag DP, Cane MA. 2004. Surface water mixing in the Solomon Sea as documented by a high-resolution coral ${ }^{14} \mathrm{C}$ record. Journal of Climate 17(5):1147-56.

Hansen B, Østerhus S. 2000. North Atlantic-Nordic seas exchanges. Progress in Oceanography 45(2):109208.

Helama S, Schöne BR, Kirchhefer AJ, Nielsen JK, Rodland DL, Janssen R. 2007. Compound response of marine and terrestrial ecosystems to varying climate: preanthropogenic perspective from bivalve shell growth increments and tree-rings. Marine Environmental Research 63(3):185-99.

Hughen KA, Baillie MGL, Bard E, Beck JW, Bertrand CJH, Blackwell PG, Buck CE, Burr GS, Cutler KB, Damon PE, Edwards RL, Fairbanks RG, Friedrich M, Guilderson TP, Kromer B, McCormac G, Manning S, Bronk Ramsey C, Reimer PJ, Reimer RW, Remmele S, Southon JR, Stuiver M, Talamo S, Taylor FW, van der Plicht J, Weyhenmeyer CE. 2004. Marine04 marine radiocarbon age calibration, $0-26 \mathrm{cal} \mathrm{kyr}$ BP. $R a-$ diocarbon 46(3):1059-86.

Jiang H, Eiríksson J, Schulz M, Knudsen KL, Seidenkrantz M-S. 2005. Evidence for solar forcing of seasurface temperature on the North Icelandic Shelf during the late Holocene. Geology 33(1):73-6.

Jones DS. 1980. Annual cycle of shell growth increment formation in two continental shelf bivalves and its paleoecologic significance. Paleobiology 6(3):331-40.

Jónsson S. 1992. Sources of fresh water in the Iceland Sea and mechanisms for governing its interannual variability. ICES Marine Science Symposia 95:62-7.

Jónsson S. 2007. Volume flux and fresh water transport associated with the East Icelandic Current. Progress in Oceanography 73(3-4):231-41.

Kilbourne KH, Quinn TM, Guilderson TP, Webb RS, Taylor FW. 2007. Decadal- to interannual-scale source water variations in the Caribbean Sea recorded by $\mathrm{Pu}$ erto Rican coral radiocarbon. Climate Dynamics 29(1):51-62.

Knudsen KL, Eiríksson J, Jansen E, Jiang H, Rytter F, Gudmundsdóttir ER. 2004a. Palaeoceanographic changes off North Iceland through the last 1200 years: foraminifera, stable isotopes, diatoms and ice rafted debris. Quaternary Science Reviews 23(20-22):223146.
Knudsen KL, Jiang H, Jansen E, Eiríksson J, Heinemeier J, Seidenkrantz M-S. 2004b. Environmental changes off North Iceland during the deglaciation and the Holocene: foraminifera, diatoms and stable isotopes. $\mathrm{Ma}$ rine Micropaleontology 50(3-4):273-305.

Larsen G, Eiríksson J, Knudsen KL, Heinemeier J. 2002. Correlation of late Holocene terrestrial and marine tephra markers, north Iceland: implications for reservoir age changes. Polar Research 21(2):283-90.

Malmberg S-A, Jónsson S. 1997. Timing of deep convection in the Greenland and Iceland seas. ICES Journal of Marine Science 54(3):300-9.

Marchitto Jr TM, Jones GA, Goodfriend GA, Weidman CR. 2000. Precise temporal correlation of Holocene mollusk shells using sclerochronology. Quaternary Research 53(2):236-46.

Marsh R, Petrie B, Weidman CR, Dickson RR, Loder JW, Hannah CG, Frank K, Drinkwater K. 1999. The 1882 tilefish kill - a cold event in shelf waters off the northeastern United States? Fisheries Oceanography 8(1): 39-49.

Pilcher JR, Baillie MGL, Brown DM, McCormac FG, MacSweeney PB, McLawrence AS. 1995. Dendrochronology of subfossil pine in the north of Ireland. Journal of Ecology 83(4):665-71.

Ropes JW. 1984. Procedures for preparing acetate peels and evidence validating the annual periodicity of growth lines formed in the shells of ocean quahogs, Arctica islandica. Marine Fisheries Review 46(2):2735.

Schöne BR, Oschmann W, Rössler J, Castro ADF, Houk SD, Kröncke I, Dreyer W, Janssen R, Rumohr H, Dunca E. 2003. North Atlantic Oscillation dynamics recorded in shells of a long-lived bivalve mollusk. $G e$ ology 31(12): 1037-40.

Schöne BR, Castro ADF, Fiebig J, Houk SD, Oschmann W, Kröncke I. 2004. Sea surface water temperatures over the period 1884-1983 reconstructed from oxygen isotope ratios of a bivalve mollusk shell (Arctica islandica, southern North Sea). Palaeogeography, Palaeoclimatology, Palaeoecology 212(3-4):215-32.

Schöne BR, Fiebig J, Pfeiffer M, Gle $\beta$ R, Hickson J, Johnson ALA, Dreyer W, Oschmann W. 2005a. Climate records from a bivalve Methuselah (Arctica islandica, Mollusca; Iceland). Palaeogeography, Palaeoclimatology, Palaeoecology 228(1-2):130-48.

Schöne BR, Dunca E, Fiebig J, Pfeiffer M. 2005b. Mutvei's solution: an ideal agent for resolving microgrowth structures of biogenic carbonates. Palaeogeography, Palaeoclimatology, Palaeoecology 228(1-2):149-66.

Scourse J, Richardson C, Forsythe G, Harris I, Heinemeier J, Fraser N, Briffa K, Jones P. 2006. First crossmatched floating chronology from the marine fossil record: data from growth lines of the long-lived bivalve mollusc Arctica islandica. The Holocene 16(7): 967-74. 
Sicre M-A, Jacob J, Ezat U, Rousse S, Kissel C, Yiou P, Eiríksson J, Knudsen KL, Jansen E, Turon J-L. 2008. Decadal variability of sea surface temperatures off North Iceland over the last 2000 years. Earth and Planetary Science Letters 268(1-2):137-42.

Stefánsson U. 1962. North Icelandic waters. Rit Fiskideildar 3:1-269.

Stuiver M, Polach HA. 1977. Discussion: reporting of ${ }^{14} \mathrm{C}$ data. Radiocarbon 19(3):355-63.

Swift JH. 1986. The Arctic waters. In: Hurdles BG, editor. Nordic Seas. Volume 3. New York: Springer-Verlag. p 129-53.

Swift JH, Aagaard K. 1981. Seasonal transitions and water mass formation in the Iceland and Greenland seas. Deep-Sea Research Part A 28(10):1107-29.

Tauber H, Funder S. 1975. ${ }^{14} \mathrm{C}$ content of recent molluscs from Scoresby Sund, central East Greenland. Grønlands Geologiske Unders $\phi$ gelese, Rapport 75:95-9.

Thompson I, Jones DS, Dreibelbis D. 1980. Annual internal growth banding and life history of the ocean quahog Arctica islandica (Mollusca: Bivalvia). Marine Biology 57(1):25-34.

Vogel JS, Southon JR, Nelson DE, Brown TA. 1984. Performance of catalytically condensed carbon for use in accelerator mass spectrometry. Nuclear Instruments and Methods in Physics Research B 5(2):289-93.

Wanamaker Jr AD, Kreutz KJ, Schöne BR, Pettigrew N,
Borns HW, Introne DS, Belknap D, Maasch KA, Feindel S. 2008. Coupled North Atlantic slope water forcing on Gulf of Maine temperatures over the past millennium. Climate Dynamics 31(2-3):183-94.

Weidman CR, Jones GA. 1993. A shell-derived time history of bomb ${ }^{14} \mathrm{C}$ on Georges Bank and its Labrador Sea implications. Journal of Geophysical ResearchOceans 98(C8):14,577-88.

Weidman CR, Jones GA, Lohmann KC. 1994. The longlived mollusc Arctica islandica: a new paleoceanographic tool for the reconstruction of bottom temperatures for the continental shelves of the northern North Atlantic Ocean. Journal of Geophysical ResearchOceans 99(C9):18,305-14.

Witbaard R. 1996. Growth variations in Arctica islandica L. (Mollusca): a reflection of hydrography-related food supply. ICES Journal of Marine Science 53(6): 981-7.

Witbaard R, Duineveld GCA, DeWilde PAWJ. 1997. A long-term growth record derived from Arctica islandica (Mollusca, Bivalvia) from the Fladen Ground (northern North Sea). Journal of the Marine Biological Association of the United Kingdom 77(3):801-16.

Witbaard R, Jansma E, Klaassen US. 2003. Copepods link quahog growth to climate. Journal of Sea Research 50(1):77-83. 